Article

\title{
Adsorption Properties of Sepiolite in Relation to Uranium and Lanthanide Ions
}

\author{
Agnieszka Gładysz-Płaska $\mathbb{D}$
}

Faculty of Chemistry, Maria Curie-Skłodowska University, Sq. M. Curie-Skłodowskiej 5, 20-031 Lublin, Poland; a.gladysz-plaska@poczta.umcs.lublin.pl

Received: 23 August 2019; Accepted: 1 November 2019; Published: 6 November 2019

\begin{abstract}
The batch technique was used to study the adsorption of $\mathrm{La}(\mathrm{III}), \mathrm{Eu}(\mathrm{III}), \mathrm{Lu}(\mathrm{III})$, and $\mathrm{U}(\mathrm{VI})$ ions on sepiolite and ODTMA-sepiolite under ambient conditions. The effects of $\mathrm{pH}$, time, and initial concentration were investigated. The highest $\mathrm{U}(\mathrm{VI})$ adsorption was found on ODTMA-sepiolite in the $\mathrm{pH}$ range of $6-8$, while in the case of lanthanide ions, adsorption on sepiolite was $80 \%$ in the $\mathrm{pH}$ range of $4-8$ and $98 \%$ for $\mathrm{pH}$ values above 8 . The adsorption capacity of ODTMA-sepiolite was found to be $285.6 \mathrm{mg} / \mathrm{g}$ for uranium, and raw sepiolite: $142.8 \mathrm{mg} / \mathrm{g}$ for U(VI), $91.6 \mathrm{mg} / \mathrm{g}$ for La(III), $91.4 \mathrm{mg} / \mathrm{g}$ for $\mathrm{Eu}$ (III), and $104.9 \mathrm{~mol} / \mathrm{g}$ for $\mathrm{Lu}(\mathrm{III})$. ODTMA-sepiolite turned out to be a weak sorbent for lanthanide ions. Two short- and long-lived fluorescence species were observed in the TRLFS spectra of $\mathrm{U}(\mathrm{VI})$ adsorbed on sepiolite at $\mathrm{pH}$ 6.5. The average lifetimes of short- $(\tau 1)$ and long-lived ( $\tau 2$ ) fluorescence are $\tau 1=2420 \pm 430 \mathrm{~ns}$ and $\tau 2=37950 \pm 5710 \mathrm{~ns}$ for U-sepiolite; $\tau 1=3523 \pm 160 \mathrm{~ns}$ and $\tau 2=45400 \pm 1830 \mathrm{~ns}$ for U-ODTMA-sepiolite.
\end{abstract}

Keywords: ODTMA-sepiolite; uranium; lanthanides; adsorption; FTIR

\section{Introduction}

Uranium, an actinide element, is of significant importance in the fuel cycle, beginning as a source and ending up as the final waste component. Anthropological sources of $U$ contamination fall into three categories: originating from weapon production, nuclear energy, and various other uses [1]. Uranium occurs in both seawater and a large number of rocks with 2 to 4 parts per million concentrations in the Earth's crust. $\mathrm{UO}_{2}{ }^{2+}$ is the main form of released uranium in the environment. A major environmental problem, however, is its contamination (radioactivity and toxicity). The methods of uranium(VI) ions removal-adsorption, solvent extraction, or ion exchange for $\mathrm{U}(\mathrm{VI})$ purification from waste waters-have been recently elaborated upon. Currently, adsorption based on metal oxides [2] —activated carbon [3] aluminosilicates [4-6] as adsorbents-is the most common method of uranium removal in aquatic environments. Zeolites, wood powder, clay, and chitosan, which are natural products, as well as those of microbiological biomass, are regarded as affordable adsorbents because of their low price and accessibility [7]. Hence, researchers have been focusing on effective natural adsorbents.

This paper discusses $\mathrm{U}(\mathrm{VI})$ and the three lanthanide ions' ( $\mathrm{La}, \mathrm{Eu}, \mathrm{Lu})$ adsorption on sepiolite, a natural adsorbent. Lanthanides are regarded as chemical analogs of actinides; thus, it is interesting to compare the adsorption capacity of sepiolite in relation to such ions. The presence of lanthanides in our environment is associated with their ever-increasing importance in everyday life-applications in fiber optic lasers, as ionic conductive oxides, or in microelectronics as oxides. They can also be used as liquid crystals or surfactants. Thus, there is a great demand for increased mining of ores containing lanthanides, propelling the mobility of rare earth elements (REE) and subsequently resulting in a higher REE content in various organisms [8]. It is commonly believed that lanthanides do not play a great role in physiological reactions in living organisms. Although they are not known to be necessary 
for metabolic processes, they can have a positive effect under certain conditions. As follows from recent toxicological investigations on chlorides of rare elements, the toxicity of lanthanides is similar to that of $\mathrm{CdCl}_{2}[7-10]$.

The main objectives of this paper were to investigate and compare uranium ions and the sorption of three lanthanides on natural sepiolite with the formula $\left(\mathrm{Si}_{12}\right) \mathrm{Mg}_{8} \mathrm{O}_{30}(\mathrm{OH})_{6}\left(\mathrm{OH}_{2}\right)_{4} \cdot 8 \mathrm{H}_{2} \mathrm{O}$ [10] or on the modified ODTMA (octadecyltrimethylammonium bromide). We took into account the fact that reports of sorption of $\mathrm{U}(\mathrm{VI})$ are scare in the literature in comparison to that of lanthanide ions. To supplement the description and effectiveness of the adsorption system, adsorption at $\mathrm{pH}$, in time, and at the initial concentration of adsorbent ions function was investigated. We used two types of adsorbents: natural and modified with organic salt (organoclays have a greater affinity for uranyl ions [11-16]). The structure of clay changes from hydrophilic to hydrophobic with the incorporation of large organic cations. Thus, organoclay, being a hybrid material, is able to adsorb inorganic and organic impurities (such as aliphatic or aromatic hydrocarbons [17]) as anions such as $\mathrm{I}^{-}, \mathrm{Cl}^{-}$, phospate(V) with cations, i.e., $\mathrm{Pb}^{2+}, \mathrm{Hg}^{2+}, \mathrm{UO}_{2}{ }^{2+}$ found in nuclear waste [18].

\section{Materials and Methods}

\subsection{Materials}

Sepiolite was delivered by Anadolu Endüstri Mineralleri (Turkey). Its chemical composition is presented in Table 1. The natural sepiolite was treated with octadecyltrimethylammonium bromide (ODTMA-Br), $\mathrm{C}_{21} \mathrm{H}_{46} \mathrm{~N} \cdot \mathrm{Br}, \mathrm{FW}: 392.52$ (Sigma-Aldrich, Steinheim, Germany) in order to intensify adsorption. Organoclay was prepared as follows: $100 \mathrm{~cm}^{3}$ of 1 or $5 \mathrm{mmol} / \mathrm{dm}^{3}$ ODTMA-Br solution was mixed with $1 \mathrm{~g}$ of sepiolite at $60^{\circ} \mathrm{C}$ for $4 \mathrm{~h}$. The sepiolite was then removed from the solution via filtration, washed twice with distilled water, dried in air, and after powdering in the agate mortar was passed through a $0.1 \mathrm{~mm}$ sieve. This sepiolite was designated as ODTMA-sep.

Table 1. Chemical composition (\%) of sepiolite.

\begin{tabular}{cccccccccc}
\hline $\mathrm{SiO}_{\mathbf{2}}$ & $\mathrm{Al}_{\mathbf{2}} \mathbf{O}_{\mathbf{3}}$ & $\mathrm{Fe}_{\mathbf{2}} \mathbf{O}_{\mathbf{3}}$ & $\mathrm{MnO}$ & $\mathbf{M g O}$ & $\mathbf{C a O}$ & $\mathrm{Na}_{\mathbf{2}} \mathbf{O}$ & $\mathbf{K}_{\mathbf{2}} \mathbf{O}$ & $\mathrm{TiO}_{\mathbf{2}}$ & $\mathbf{P}_{\mathbf{2}} \mathbf{O}_{\mathbf{5}}$ \\
\hline 42.19 & 0.87 & 0.48 & 0.006 & 22.90 & 10.30 & $<0.01$ & 0.19 & 0.05 & 0.02 \\
\hline
\end{tabular}

\subsection{Sorption Determination}

Adsorption was studied by means of the batch method at $23^{\circ} \mathrm{C}$. Mixtures $\left(100 \mathrm{~cm}^{3}\right)$ were prepared with $0.1 \mathrm{~g}$ of adsorbent and $\mathrm{UO}_{2}\left(\mathrm{COOCH}_{3}\right)_{2} \cdot 2 \mathrm{H}_{2} \mathrm{O}$ solution or $\mathrm{Ln}\left(\mathrm{NO}_{3}\right)_{3}(\mathrm{Ln}=\mathrm{La}$, Eu or $\mathrm{Lu})$ with the desired concentration of ions. They were then shaken for $6 \mathrm{~h}$, filtered using filter paper (Filtrak 390), and centrifuged at 10,000 rpm for $10 \mathrm{~min}$. The amount of $\mathrm{U}(\mathrm{VI})$ or $\mathrm{Ln}(\mathrm{III})$ ions adsorbed on sepiolite was determined based on the difference between the initial and equilibrium concentrations using the following equation:

$$
\begin{gathered}
c_{s}=\left(c_{i n}-c_{e q}\right) \times \frac{V}{m} \\
A \%=\frac{\left(c_{i n}-c_{e q}\right)}{c_{i n}} \times 100 \%
\end{gathered}
$$

where $c_{a d s}, c_{i n}, c_{e q}$ are the concentrations of $\mathrm{Ln}(\mathrm{III})$ or $\mathrm{U}(\mathrm{VI})$ ions in the clay phase, in the initial and equilibrium solutions, respectively; $A \%$ means the adsorption percentage in the aqueous solution. $V$ and $m$ indicate solution volume $\left(\mathrm{cm}^{3}\right)$ and adsorbent mass $(\mathrm{mg})$. The concentrations of $\mathrm{U}(\mathrm{VI})$ and lanthanides were determined by the Arsenazo III method [19]. To this end, uranium solutions or a corresponding lanthanide with the addition of $0.05 \%$ Arsenazo(III), formic buffor of $\mathrm{pH} 2.6$ as well as $1 \%$ ascorbic acid, was used. The absorbance of these solutions was measured by means of spectrophotometer Jasco 660 at wavelengths $650 \mathrm{~nm}$ and $655 \mathrm{~nm}$ for lanthanides and uranium ions, respectively. 
Kinetic experiments and study of the $\mathrm{pH}$ value effect were conducted at an initial concentration of $0.5 \mathrm{mmol} / \mathrm{dm}^{3}$. The PH effect from uranium or lanthanide ions' adsorption was in the $\mathrm{pH}$ range 2-11. $\mathrm{HNO}_{3}$ or $\mathrm{NaOH}$ solution was added to adjust the $\mathrm{pH}$ value. All experimental data were averaged with triplicate determinations. Data errors were about $5 \%$.

\subsection{Methods}

Sorbent surface morphology was observed using a scanning electron microscope, Quanta 3D FEG, FEI Company, Hillsboro, OR, USA.

Clay spectra were recorded using the Nicolet 8700A FT-IR spectrometer (Thermo Scientific, Waltham, MA, USA, 2009), with TGS detector of $1 \mathrm{~cm}^{-1}$ resolution in transmission mode at room temperature. The $\mathrm{KBr}$ pellet technique (1:20) was applied. After drying at $200{ }^{\circ} \mathrm{C}$ for $24 \mathrm{~h}, 560 \mathrm{mg} \mathrm{KBr}$ was homogenized with sepiolite in a ball grinder (Narva, Brand-Erbisdorf, Germany). Tablets with 1 $\mathrm{cm}$ radius and thickness of $0.1 \mathrm{~cm}$ were prepared by means of a hydraulic press.

Nitrogen adsorption was measured at $77 \mathrm{~K}$ by volumetric analyzer AUTOSORB-1CMS (Quantachrome Instruments, Boynton Beach, FL, USA, 2005). Before measurements, each sample was degassed at $100{ }^{\circ} \mathrm{C}$ for minimum $6 \mathrm{~h}$ to obtain $10^{-3} \mathrm{hPa}$.

XRD analysis was performed by means of a diffractometer equipped with a Rtg generator of the ISO-DEBYFLEX 303-60 kV type, produced by Seifert Analytical X-ray (Middle Watch, Swavesey, UK), and a cooling system KMW 3000C from Rigaku Oxford Diffraction (Abingdon, UK). The measurement data were collected, analyzed, and processed using the XRAYAN program (version 4.2.2, KOMA, Warsaw, Poland).

An ESCA apparatus with multidetection electron analyzer Scienta R4000 (VG Scienta) (CEO Scienta Omicron Company GmbH, Taunusstein, Germany) was used to record XPS spectra in the fixed transmission mode. An unmonochromatized $\mathrm{Al} \mathrm{K} \alpha$ source $(1,253.6 \mathrm{eV})$ with $12 \mathrm{kV}$ voltage and $30 \mathrm{~mA}$ emission current was also employed. After powdering, the samples were kept in a molybdenum holder in $5 \times 10^{-8}$ mbar vacuum. The CASA XPS software (version 2.3.22, Shimadzu Group Company, Tokyo, Japan) with a Gaussian-Lorentzian peak shape was used for U 4 f spectra fitting after background subtraction with a Shirley baseline. The uranium $4 \mathrm{f}$ spin-orbit coupling was at $10.8 \mathrm{Ev}$.

Sepiolite luminescence was registered at room temperature with a Photon Technology International fluorescence spectrophotometer using the Nd:YAG diode laser (Opolette, Quantel, Carlsbad, CA, USA).

The materials for the XPS, SEM, FTIR, and fluorescence measurements were obtained by mixing $2 \mathrm{~g}$ of the ODTMA-sep or sepiolite with $100 \mathrm{~cm}^{3}$ of $\mathrm{UO}_{2}\left(\mathrm{CH}_{3} \mathrm{COO}\right)_{2}$ or $\mathrm{Ln}\left(\mathrm{NO}_{3}\right)_{3}$ solution $\left(0.01 \mathrm{~mol} / \mathrm{dm}^{3}\right)$ for $8 \mathrm{~h}$. They were then separated by filtration, followed by drying in air.

\section{Results and Discussion}

\subsection{Surface Propetries of the Sepiolite}

A comparison of sepiolite before and after ion adsorption concludes that there is a significant decrease in the surface area of micropores and volume, total pore volume, and BET surface area during clay modification using the ODTMA-Br solution. This is a consequence of the clogging of micropores by large cations of alkylammonium salt; only mesopores remain accessible (Table 2). The average pore diameter increases as a result of reduction in the number of small pores, as well as the formation of secondary pores derived from collapsed surfactant alkyl chains. Such changes are typical of the adsorption of large organic ions [20-25]. After uranium adsorption, the values of total pore volume and average pore diameter diminished, which was attributed to the adsorption of uranium ions: $\mathrm{UO}_{2}{ }^{2+}$ or/and hydroxycomplexes: $\left(\mathrm{UO}_{2}\right)(\mathrm{OH})^{+},\left(\mathrm{UO}_{2}\right)_{3}(\mathrm{OH})_{5}{ }^{+}$. In the case of sepiolite samples saturated with lanthanide ions $\mathrm{La}, \mathrm{Eu}$, and $\mathrm{Lu}$, a significantly smaller surface reduction was observed than in the case of the sepiolite U-1mM-ODTMA or sepiolite samples $1 \mathrm{mM}-, 5 \mathrm{mM}-$ ODTMA. This can be explained by the smaller sizes of $\mathrm{Ln}^{3+}$ (about $1 \AA$ ) or Ln-O (less than 2.64 $\AA$ ) [26] compared to uranium ions that can reach $6 \AA$, depending on the type of coordination sphere. Large and smaller pores are occupied by 
small ions $\mathrm{Ln}^{3+}$ or $\mathrm{Ln}(\mathrm{OH})_{2}{ }^{+}, \mathrm{Ln}(\mathrm{OH})^{2+}, \mathrm{LnCO}_{3}{ }^{+}$, and $\mathrm{LnHCO}_{3}{ }^{2+}$ and $\mathrm{Ln}\left(\mathrm{NO}_{3}\right)^{+}$; and therefore, the average pore size remains smaller than that of the ODTMA sepiolite and U-ODTMA sepiolite samples. In each case, the BET surface is also reduced, as a result of ion adsorption.

Table 2. Textural analysis of sepiolite.

\begin{tabular}{|c|c|c|c|c|c|}
\hline Sample & $\begin{array}{c}\text { BET Total } \\
\text { Surface Area } \\
\left(\mathrm{m}^{2} / \mathrm{g}\right)\end{array}$ & $\begin{array}{l}\text { Micropore } \\
\text { Area }\left(\mathrm{m}^{2} / \mathrm{g}\right)\end{array}$ & $\begin{array}{l}\text { Micropore } \\
\text { Volume } \\
\left(\mathrm{cm}^{3} / \mathrm{g}\right)\end{array}$ & $\begin{array}{l}\text { Total Pore } \\
\text { Volume } \\
\left(\mathrm{cm}^{3} / \mathrm{g}\right)\end{array}$ & $\begin{array}{l}\text { Average Pore } \\
\text { Diameter (A) }\end{array}$ \\
\hline Sepiolite & 342 & 157 & 0.069 & 0.399 & 45 \\
\hline 1mM-ODTMA-sepiolite & 212 & 26 & 0.011 & 0.380 & 86 \\
\hline 5mM-ODTMA-sepiolite & 177 & 18 & 0.007 & 0.364 & 95 \\
\hline U-1mM-ODTMA-sepiolite & 162 & 10 & 0.007 & 0.323 & 98 \\
\hline La-sepiolite & 248 & 89 & 0.025 & 0.383 & 55 \\
\hline Eu-sepiolite & 253 & 91 & 0.027 & 0.384 & 58 \\
\hline Lu-sepiolite & 257 & 92 & 0.027 & 0.385 & 59 \\
\hline
\end{tabular}

\subsection{Scanning Electron Microscopy Analysis}

The surface of sepiolite modified by the surfactant and uranium is smoother and flat, when compared to that of the natural adsorbent (Figure 1). This is probably due to the layers of organic matter partially covering the sepiolite surface. Additionally, single and small grains are visible on the surface, which may be due to uranyl hydroxy carbonate or/and hydroxide as a new phase. In the XRD spectrum of U-1mM_ODTMA-sepiolite, apart from characteristic peaks for sepiolite, weak peaks derived from uranyl carbonate were also found. In addition, weak peaks of lanthanide carbonates occurred in samples of sepiolite modified with the appropriate lanthanide (Figure 2).

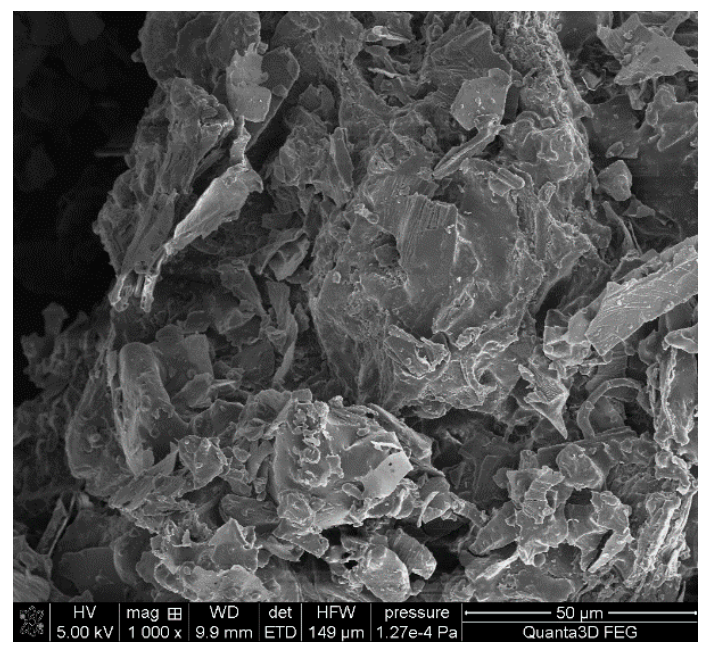

(a)

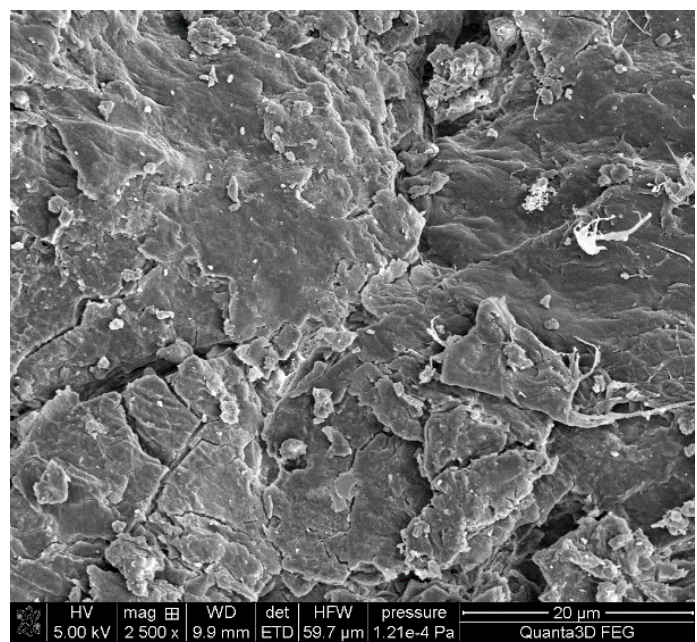

(b)

Figure 1. SEM images of sepiolite (a) and ODTMA-sepiolite-U (b). 


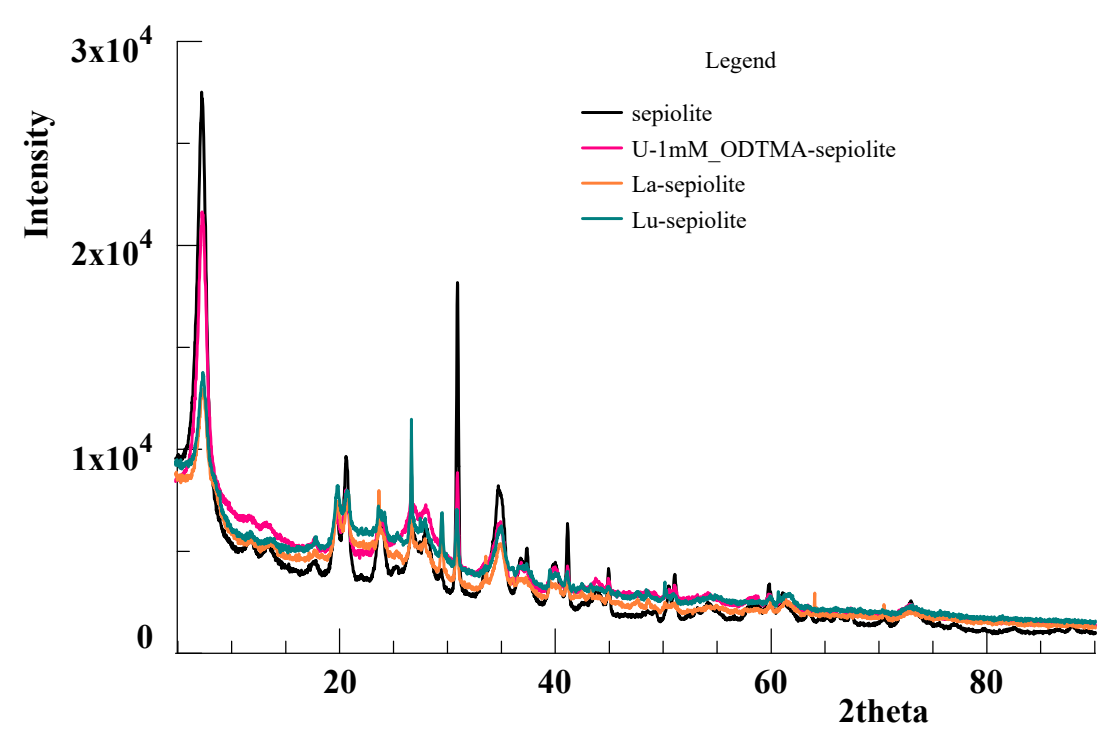

Figure 2. X-ray diffraction of sepiolite samples.

\subsection{Fourier-Transform Infrared Spectroscopy and Fluorescence Spectra of Sepiolite}

The most intensive vibrations at $800-440,1220-980 \mathrm{~cm}^{-1}, 1470-60 \mathrm{~cm}^{-1}, 1670-50 \mathrm{~cm}^{-1}$, 2930-2850 $\mathrm{cm}^{-1}$, and 3600-3400 $\mathrm{cm}^{-1}$ are shown by the sepiolite and ODTMA-sepiolite FTIR-spectra (Figure 3). The band at $441-440 \mathrm{~cm}^{-1}$ originates from the octahedral-tetrahedral bonds ( $\mathrm{Si}-\mathrm{O}-\mathrm{Mg}$ bonds) and the bands at $650-648 \mathrm{~cm}^{-1}$ correspond to vibrations of the $\mathrm{Mg}-\mathrm{OH}$ bond $[26,27]$. The bands at $690 \mathrm{~cm}^{-1}$ are assigned to the Si-O bonds deformation and bending modes [28]. Those at $483-475 \mathrm{~cm}^{-1}$ correspond to the $\mathrm{Si}-\mathrm{O}-\mathrm{Si}$ bending vibrations. The shift in the position of the last band for the U-1mM_ODTMA-sep sample indicates interactions of uranyl ions with the Si-O-Si group, while the bands in the region 1211 to $980 \mathrm{~cm}^{-1}$ belong to the $\mathrm{Si}-\mathrm{O}$ stretching vibrations. The $1211 \mathrm{~cm}^{-1}$ band shifts to $1204 \mathrm{~cm}^{-1}$ and the $980 \mathrm{~cm}^{-1}$ one to $984 \mathrm{~cm}^{-1}$ with increasing surfactant concentration (Table 3). These results point to the interactions of the surfactant molecules and the clay siloxane layer (surface). In the case of Ln-sepiolite samples ( $\mathrm{Ln}$ means $\mathrm{La}, \mathrm{Eu}$, or $\mathrm{Lu}$ ), the band shift in the range of 400-600 and 900-1200 indicates interactions of lanthanide ions with the $\mathrm{Si}-\mathrm{O}$ moieties and $\mathrm{Mg}^{2+}$ ions.

Adsorbed water affects the $\mathrm{H}-\mathrm{O}-\mathrm{H}\left(1600-1700 \mathrm{~cm}^{-1}\right)$ and $\mathrm{O}-\mathrm{H}$ stretching $\left(3200-3700 \mathrm{~cm}^{-1}\right)$ regions. The band position is gradually shifted from $1663 \mathrm{~cm}^{-1}$ to $1659 \mathrm{~cm}^{-1}$ with increasing concentrations of the surfactant. At the same time, a remarkable decrease of absorption intensity was observed, pointing to a smaller number of hydrogen-bound $\mathrm{H}_{2} \mathrm{O}$ molecules in the organoclay; this is characterized by a higher surfactant concentration, possibly caused by the reduction of $\mathrm{H}_{2} \mathrm{O}$ content due to its replacement by ODTMA ${ }^{+}$. As a result of surfactant intercalation, sepiolite surface properties are modified-hydrophilic to hydrophobic. At the same time, U(VI) ions' adsorption on the sepiolite surface contributes to this band intensity increase, which is related to strong hydration of uranyl ions. A similar case is observed for those in the $3200-3420 \mathrm{~cm}^{-1}$ area, associated with the stretching vibrations of structural $\mathrm{OH}$ groups and adsorbed water. These bands show little dependence on surfactant concentration. A slight shift of the bands towards higher wavenumbers is observed with a decrease in water content in the ODTMA-sep. Their intensity growth decreases with increasing surfactant concentration after U(VI) ions' adsorption. At 2855 and $2928 \mathrm{~cm}^{-1}$ bands, they are equal to symmetric and asymmetric stretching modes of $\mathrm{CH} 2$ groups derived from the surfactant, i.e., ODTMA. Their intensity grows gradually with increasing ODTMA concentration, resulting in the rise of amine chains packing density in sepiolite galleries. Tensile frequencies of $\mathrm{CH} 2$ groups are sensitive to conformational changes and depend on amine concentration. At high ODTMA concentration, the chains remain ordered (all-trans conformation), and in the FTIR spectrum, there are narrow absorption bands with relatively constant frequency. At low concentrations of the surfactant, Gauche conformers are present, resulting in the frequency shifting towards the high waves. In the case of ODTMA-sep, the 
wavenumbers of absorption bands (symmetric and asymmetric $\mathrm{CH} 2$ stretching) change from 2856 to $2855 \mathrm{~cm}^{-1}$ and 2928 to $2930 \mathrm{~cm}^{-1}$, respectively. In the case of ODTMA-sep, the wavenumbers of absorption bands (symmetric and asymmetric stretching of $\mathrm{CH} 2$ ) are virtually unchanged and amount to $2855 \mathrm{~cm}^{-1}$ (1mM_ODTMA-, 5mM_ODTMA-sepiolite), $2856 \mathrm{~cm}^{-1}$ ((U-1mM_ODTMA)-sepiolite); and 2928, 2929, $2930 \mathrm{~cm}^{-1}$, respectively. The band between 1463 and $1459 \mathrm{~cm}^{-1}$ may be linked with $\mathrm{C}-\mathrm{O}-\mathrm{H}$ or $\mathrm{C}-\mathrm{H}$ groups vibrations [27]. Its frequency is less sensitive to conformation of the amine chain; therefore, we do not observe a change in the position of this band with an increase in the ODTMA cation content in the sample. In the case of a sample of sepiolite with the adsorbed uranyl ions, the intensity of this band decreases and its position varies from 1463 to $1459 \mathrm{~cm}^{-1}$. This may indicate interactions between the uranyl ions and the alkyl chains of the surfactant cation.

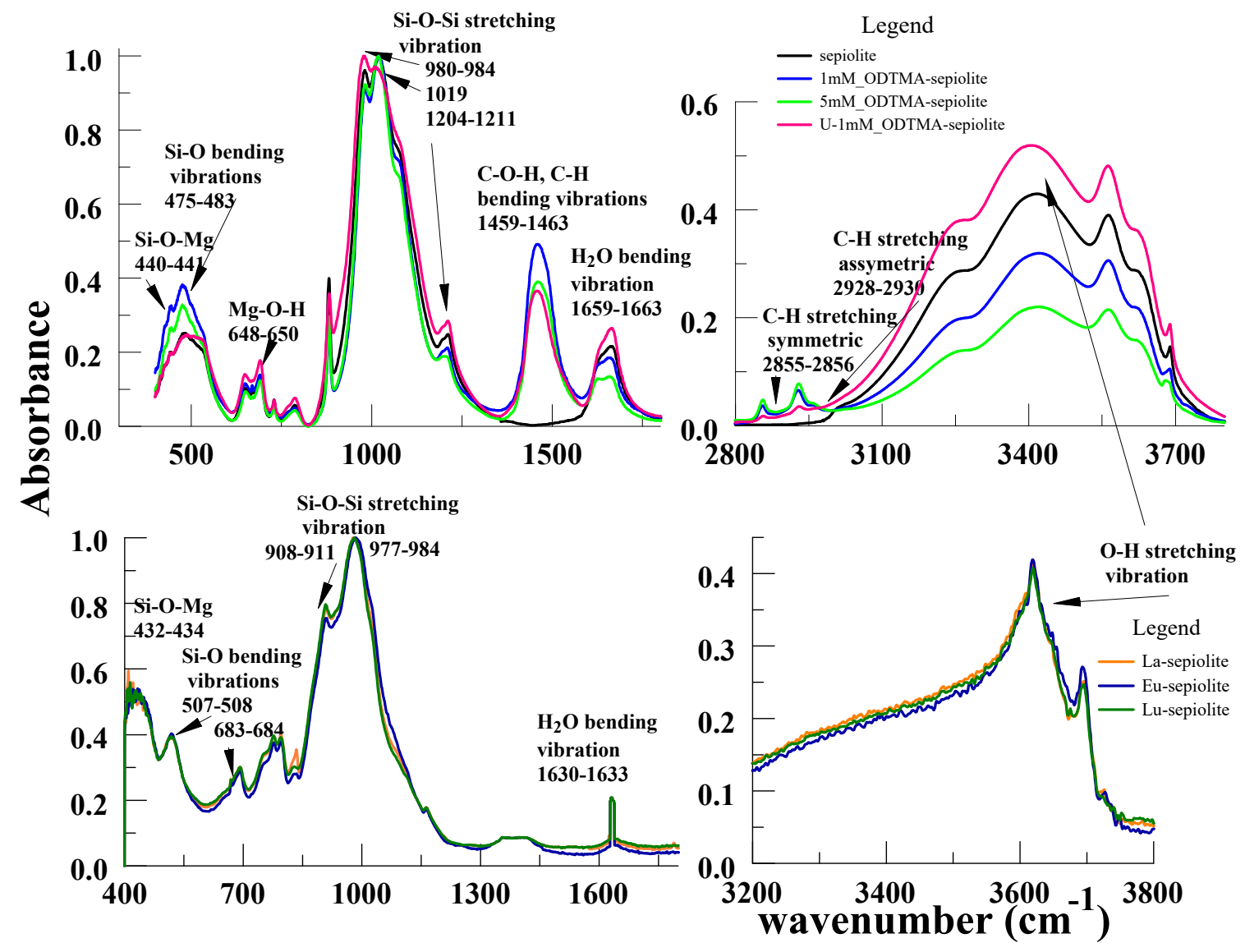

Figure 3. Sepiolite FTIR spectra. (Coloured figure online.)

The kind of U(VI) surface complexes on sepiolite was investigated by applying the time-resolved laser-induced fluorescence spectroscopy (TRLFS). It obtained information on the lifetime of the adsorbed species and spectral characteristics indicating the number of species and their spectral identities. Information about fluorescence emission bands position and fluorescence lifetime can be obtained using uranium(VI) species TRLFS measurements. The number of U(VI) atoms surrounding the water molecules affects the fluorescence lifetime. As follows from the TRLFS spectra of U(VI) surface species adsorbed on sepiolite at $\mathrm{pH} 6.5$, there are at least two surface species with different fluorescence lifetimes, namely: a short-lived one and a long-lived one. The average short- $\left(\tau_{1}\right)$ and long-lived $\left(\tau_{2}\right)$ species fluorescence lifetimes for U-sepiolite are: $\tau_{1}=2420 \pm 430 \mathrm{~ns}$ and $\tau_{2}=37950 \pm 5710 \mathrm{~ns}$; for U-ODTMA-sepiolite: $\tau_{1}=3523 \pm 160 \mathrm{~ns}$ and $\tau_{2}=45400 \pm 1830 \mathrm{~ns}$. Shorter fluorescence lifetimes indicate more water molecules in the coordination environment-it indicates a quenching by water molecules [29-31]. Thus, U(VI) forms two surface species on sepiolite, differing in the number of water molecules in the coordination environment. The comparison of fluorescence lifetimes with and 
without ODTMA shows remarkably longer fluorescence lifetimes of both species with ODTMA. Shorter U_ODTMA-sep fluorescence lifetimes point to a larger number of water molecules in the coordination environment of corresponding U(VI) surface species. According to Bauman et al. [30], surface species with shorter fluorescence lifetime can be a result of bidentate mononuclear inner-sphere surface complexes, where $\mathrm{U}(\mathrm{VI})$ is bound to reactive hydroxyl groups at the broken edge connected with an $\mathrm{Al}$ molecule. Surface species with shorter fluorescence lifetime were assigned by Arnold et al. [7] to the inner-sphere bidentate surface complex, where $\mathrm{U}(\mathrm{VI})$ is bound to the aluminol groups of muscovite edge-surfaces. According to both scientists, surface species with remarkably longer fluorescence lifetimes can be treated as an amorphous U(VI) condensate nanosized cluster of uranyl surface species.

Table 3. Position of bands $\left(\mathrm{cm}^{-1}\right)$ in the sepiolite FTIR spectra.

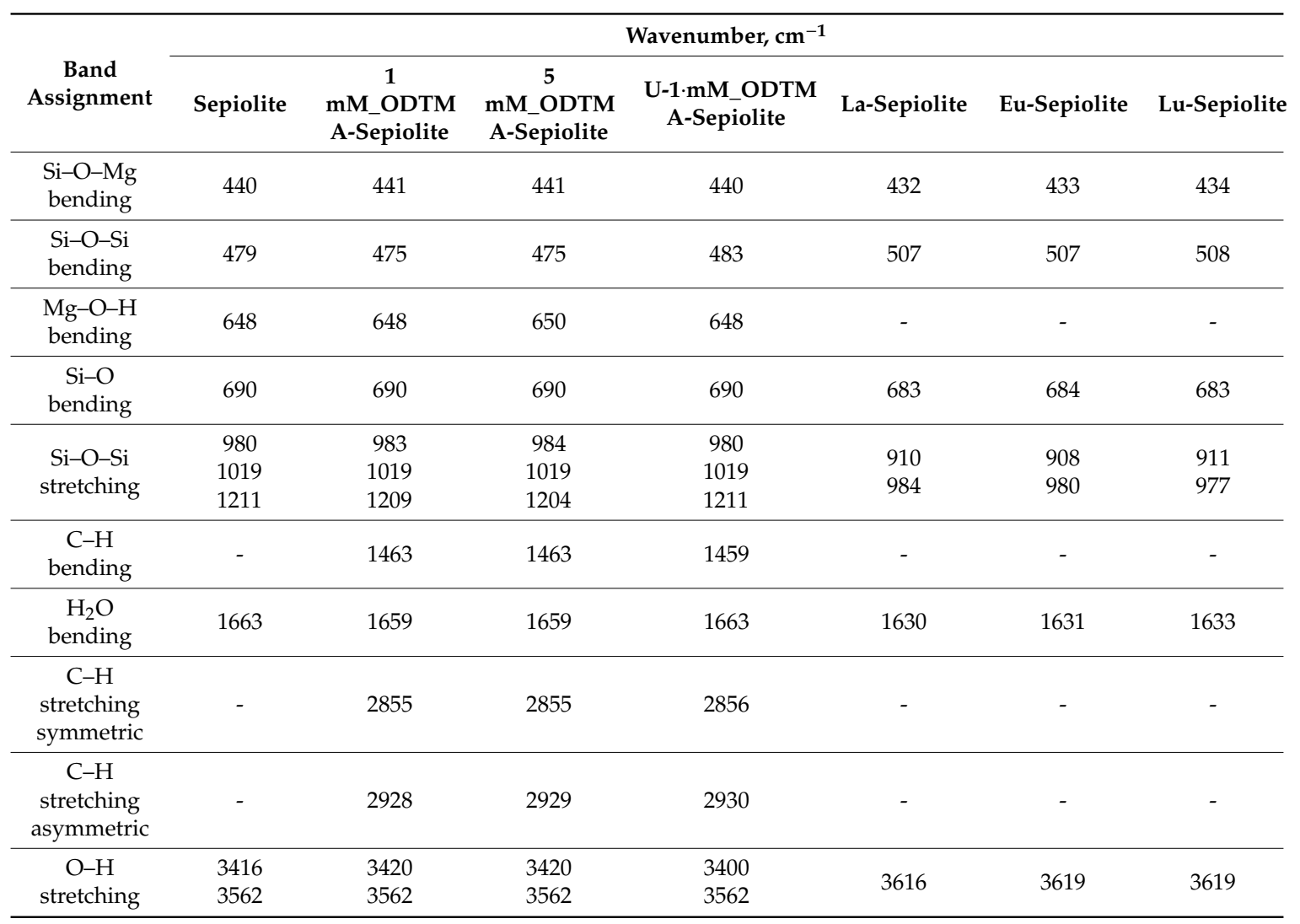

\subsection{X-ray Photoelectron Spectroscopy Analysis}

Coexistence of the $\mathrm{C}, \mathrm{O}, \mathrm{Mg}, \mathrm{Si}$, and $\mathrm{U}$ bands is illustrated by survey spectra presented in Figure 4a. Four individual peaks at 284.7, 286.3, 287.9, and $290.0 \mathrm{eV}$, which are assigned to $\mathrm{C}-\mathrm{C}, \mathrm{C}-\mathrm{O}, \mathrm{C}=\mathrm{C}$, and $\mathrm{O}=\mathrm{C}-\mathrm{O}$, respectively, make the spectrum of $\mathrm{C} 1 \mathrm{~s}$ [32]. Two peaks, the highest at 532.6 and the other one at $535.0 \mathrm{eV}$, representing the bonds of $\mathrm{SiO}_{2}$ and $\mathrm{H}_{2} \mathrm{O}$, are observed in the O1s spectrum. For the sample with uranium, it is composed of two components corresponding to the bonds of $\mathrm{SiO}_{2}$ and $\mathrm{H}_{2} \mathrm{O}$. The Si2p at $103.2 \mathrm{eV}$ and $\mathrm{Mg} 1 \mathrm{~s}$ at $1305.4 \mathrm{eV}$ spectra are also of significant importance. A slight shift in the position of Mg1s peaks from 1304.7 to $1303.8 \mathrm{eV}$ is observed for the U-1mM-ODTMA-sep sample containing uranium and up to 1312-1313.2 eV for the La-, Eu-, Lu-sepiolite samples (Table 4). The above facts may indicate a reaction between the $\mathrm{Mg}^{2+}$ ions found in the structure of sepiolite and the uranyl cations: $\mathrm{UO}_{2}{ }^{2+},\left(\mathrm{UO}_{2}\right)(\mathrm{OH})^{+},\left(\mathrm{UO}_{2}\right)_{3}(\mathrm{OH})_{5}{ }^{+}$and $\left(\mathrm{UO}_{2}\right)_{4}(\mathrm{OH})_{7}{ }^{+}$or $\mathrm{La}^{3+}, \mathrm{Eu}^{3+}$, and $\mathrm{Lu}^{3+}$, respectively. Interactions between the Si-O-Si sepiolite groups and U(VI) or Ln(III) ions are evidenced by changes in the Si2p peak position from $103.2 \mathrm{eV}$ to $102.7 \mathrm{eV}$. The occurrence of U4f7/2 and U4f5/2 peaks, corresponding to the binding forces of $382.4 \mathrm{eV}, 385.7,392.4 \mathrm{eV}$ as well as 393.2, 397, 403.2 eV, points to the presence of uranyl ions (Figure $4 \mathrm{~b}$ ). The binding energies are consistent with U(VI) and 
the peaks are associated with the presence of uranium forms such as $\left(\mathrm{UO}_{2}\right)_{3}(\mathrm{OH})_{5}{ }^{+}$and $\left(\mathrm{UO}_{2}\right)_{4}(\mathrm{OH})_{7}{ }^{+}$, as well as that of non-stoichiometric uranium (VI) oxides [33].

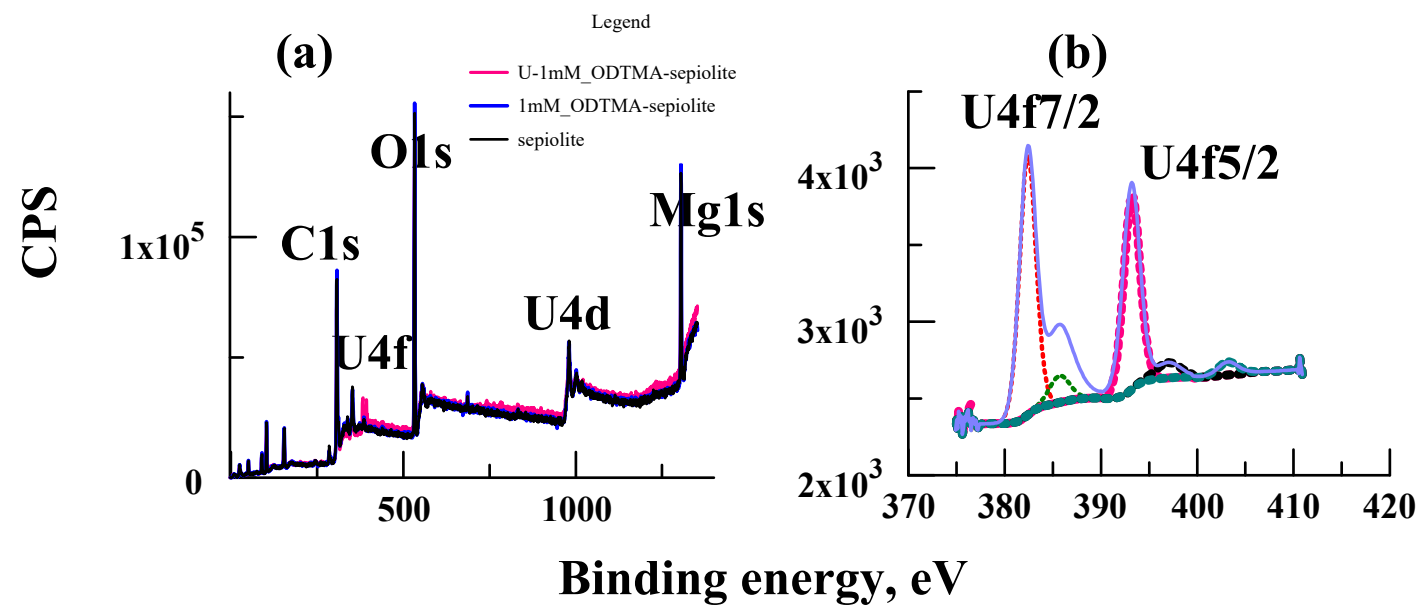

Figure 4. The survey of XPS spectra of sepiolite (a) and high-resolution scans of U4f (b). (Coloured figure online.)

Table 4. XPS data for the sepiolite samples.

\begin{tabular}{|c|c|c|c|c|c|c|c|}
\hline & Region & C1s & O1s & Mg1s & $\mathrm{Si} 2 \mathrm{p}$ & F1s & $\mathrm{U} 4 \mathrm{f} / \operatorname{Ln} 3 \mathrm{~d}$ \\
\hline \multirow{6}{*}{$\begin{array}{c}\text { Peak } \\
\text { position }\end{array}$} & sepiolite & 284.7 & 532.7 & 1304.7 & 103.2 & 686.2 & - \\
\hline & $\begin{array}{c}\text { 1mM_ODTMA- } \\
\text { sepiolite }\end{array}$ & 284.7 & 532.7 & 1304.7 & 103.2 & 686.7 & - \\
\hline & $\begin{array}{l}\text { U-1mM_ODTMA- } \\
\text { sepiolite }\end{array}$ & 284.7 & 531.2 & 1303.8 & 102.7 & 685.2 & 382.2 \\
\hline & La-sepiolite & 285.6 & 532.1 & 1312.3 & 102.8 & 686.1 & 835.6 \\
\hline & Eu-sepiolite & 285.7 & 532.2 & 1312.5 & 102.8 & 686.1 & 1136 \\
\hline & Lu-sepiolite & 285.9 & 532.4 & 1313.2 & 102.6 & 685.4 & 1345 \\
\hline \multirow{6}{*}{$\begin{array}{l}\text { Intensity } \\
\text { (CPS) }\end{array}$} & sepiolite & $25,026.5$ & 417,224 & 250,349 & $54,183.9$ & $14,863.2$ & - \\
\hline & $\begin{array}{l}\text { 1mM_ODTMA- } \\
\text { sepiolite }\end{array}$ & $31,044.6$ & 412,383 & 24,2361 & $55,103.5$ & $13,149.4$ & - \\
\hline & $\begin{array}{l}\text { U-1mM_ODTMA- } \\
\text { sepiolite }\end{array}$ & $23,433.7$ & 374,534 & 209,122 & $47,450.8$ & $13,278.8$ & $94,042.8$ \\
\hline & La-sepiolite & $21,345.3$ & 321,689 & 19,0234 & 43,555 & 11,023 & 72,346 \\
\hline & Eu-sepiolite & 22,454 & 313,222 & 198,645 & 44,356 & 12,008 & 68,955 \\
\hline & Lu-sepiolite & 22,635 & 317,890 & 197,653 & 43,864 & 12,024 & 69,034 \\
\hline \multirow{6}{*}{$\%$ At Conc } & sepiolite & 9.6 & 54.9 & 8.6 & 25.6 & 1.3 & - \\
\hline & $\begin{array}{c}\text { 1mM_ODTMA- } \\
\text { sepiolite }\end{array}$ & 11.8 & 53.3 & 8.2 & 25.6 & 1.1 & - \\
\hline & $\begin{array}{l}\text { U-1mM_ODTMA- } \\
\text { sepiolite }\end{array}$ & 10.1 & 54.9 & 8 & 24.9 & 1.3 & 0.8 \\
\hline & La-sepiolite & 8.9 & 54.6 & 6.8 & 24.3 & 1.1 & 0.5 \\
\hline & Eu-sepiolite & 8.3 & 56.2 & 6.6 & 24.8 & 1.1 & 0.49 \\
\hline & Lu-sepiolite & 8.8 & 55.7 & 6.8 & 24.9 & 1.1 & 0.5 \\
\hline \multirow{6}{*}{$\begin{array}{l}\% \text { Mass } \\
\text { Conc }\end{array}$} & sepiolite & 6 & 45.1 & 10.8 & 36.9 & 1.3 & - \\
\hline & $\begin{array}{c}\text { 1mM_ODTMA- } \\
\text { sepiolite }\end{array}$ & 7.3 & 44.1 & 10.3 & 37.1 & 1.1 & \\
\hline & $\begin{array}{l}\text { U-1mM_ODTMA- } \\
\text { sepiolite }\end{array}$ & 5.7 & 41.5 & 9.2 & 33.1 & 1.2 & 9.3 \\
\hline & La-sepiolite & 5.2 & 40.8 & 8.2 & 32.2 & 1.1 & 6.6 \\
\hline & Eu-sepiolite & 5.3 & 41.8 & 8.0 & 32.4 & 1.1 & 6.4 \\
\hline & Lu-sepiolite & 5.5 & 41.0 & 8.2 & 33.1 & 1.1 & 6.6 \\
\hline
\end{tabular}




\subsection{Equilibrium Data of Sorption on Sepiolite}

In order to describe the adsorption behavior of uranium and lanthanides on sepiolite, the Langmuir, Langmuir-Freundlich, and Dubinin-Radushkevich adsorption models were used to fit the obtained isotherms. The Langmuir behaviour was tested by the following equation in a linearized form:

$$
\frac{c_{e q}}{c_{s}}=\frac{1}{a_{\max } \times K_{L}}+\frac{1}{a_{\max }} \times c_{e q}
$$

The following is the expression for the Langmuir-Freundlich isotherm:

$$
c_{S}=\frac{a\left(K_{L-F} \times c_{e q}\right)^{n}}{\left[1+\left(K_{L-F} \times c_{e q}\right)^{n}\right]}
$$

The apparent adsorption energy was estimated using the Dubinin-Radushkevich isotherm. Its linear form is as follows:

$$
\left.\ln \left(c_{s}\right)=\ln \left(q_{m}\right)-K_{D-R} \times\left[R T \times \exp \left(1+\frac{1}{c_{e q}}\right)\right]^{2}\right)
$$

where, $c_{s}$ and $c_{e q}$ are the equilibrium concentrations of $\mathrm{U}(\mathrm{VI})$ in the clay (mol/g) and aqueous phases $\left(\mathrm{mol} / \mathrm{dm}^{3}\right), a_{\max }, q_{m}, K, n$-the adsorption maximum, maximum capacity, adsorption constant, heterogeneity parameter of the surface, respectively. $R$ denotes the gas constant $(8.314 \mathrm{~J} / \mathrm{mol} \mathrm{K}), T$ represents the absolute temperature $(\mathrm{K})$. The parameter values calculated based on the intercept slopes of the plots are included in Table 5. Adsorption apparent energy $(E)$ can be determined from:

$$
E=\left(\frac{1}{\sqrt{2 K_{D-R}}}\right)
$$

Table 5. Parameters of the isotherms and kinetic models of the U(VI) and lanthanide ions adsorption on sepiolite, calculated by experimental data fitting ( $\mathrm{pH} 6$ and $23^{\circ} \mathrm{C}$ ).

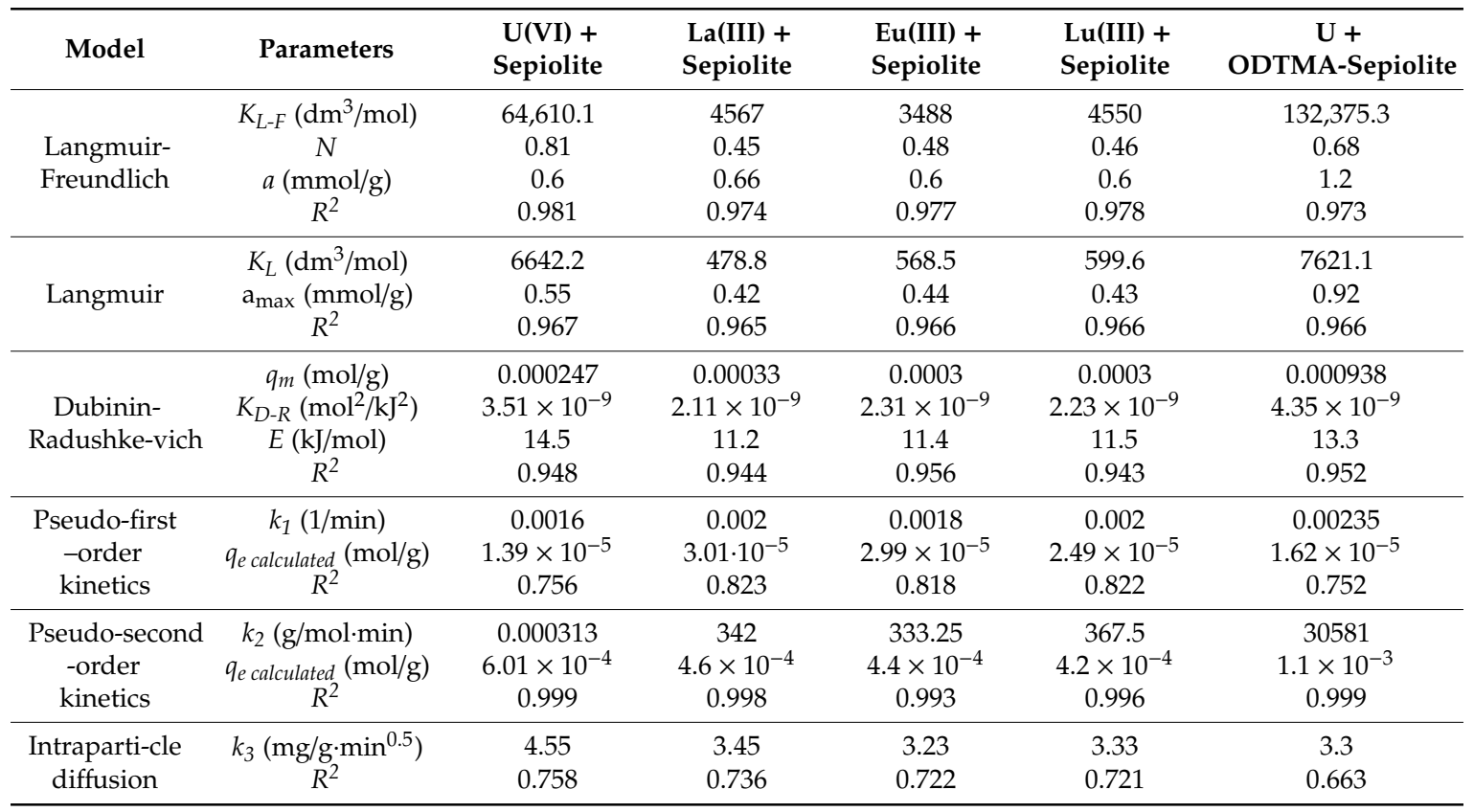

The adsorption isotherm of uranium ions on ODTMA-sep shows an increasing tendency (Figure 5a). The rapid increase in adsorption is observed for concentrations higher than $0.11 \mathrm{mmol} / \mathrm{dm}^{3}$. As expected, 
the uranyl ions' adsorption on ODTMA-sep is much higher than that on natural sepiolite for the studied initial concentration range. Studies on the parameters of isotherms and coefficients of correlation $\left(R^{2}\right)$ (Table 5) show that the Langmuir-Freundlich model is the best for description of U(VI) adsorption on natural sepiolite $\left(R^{2}=0.98\right)$ and ODTMA-sep $\left(R^{2}=0.97\right)$. The parameter value of $n<1$ points to the significant heterogeneity of the sorbent surface. The energy value calculated on the basis of the Dubinin-Radushkevich isotherm equation ( $E=14.5$ and $13.3 \mathrm{~kJ} / \mathrm{mol})$ indicates that chemisorption is the dominant mechanism.

(a)

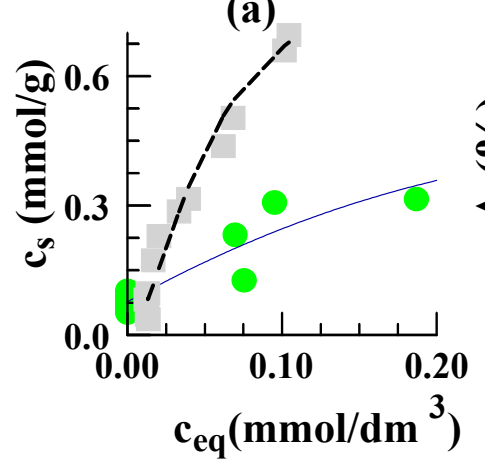

(b)

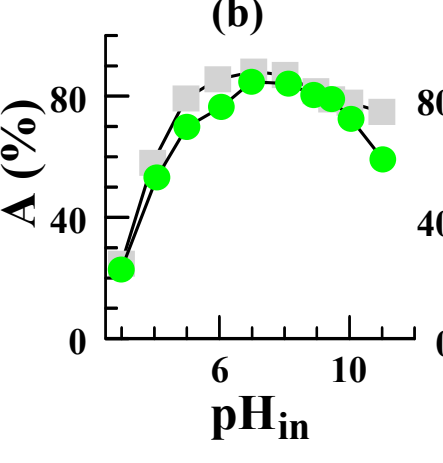

(c)

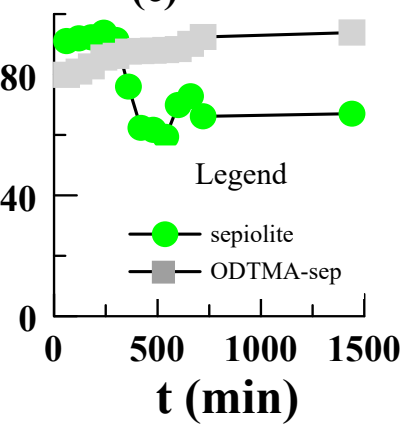

Figure 5. The influence of initial concentration (a), $\mathrm{pH}(\mathbf{b})$, and time (c) on U(VI) ions adsorption on ODTMA- and natural sepiolite at $23^{\circ} \mathrm{C}$. (Coloured figures online.)

The adsorption of $\mathrm{La}^{3+}, \mathrm{Eu}^{3+}$, and $\mathrm{Lu}^{3+}$ ions on natural sepiolite is in the range of $0.4-0.48 \mathrm{mmol} / \mathrm{g}$ and, as expected, much higher than on the modified form with ammonium salt, i.e., ODTMA-sepiolite. Lanthanide adsorption isotherms show an upward trend and saturation of the adsorbent monolayer has not been reached the range of the tested concentrations $\left(0.1-1 \mathrm{mmol} / \mathrm{dm}^{3}\right)$ (Figure 6a). The parameters from the isothermal modelling are presented in Table 5 . The values of energy for individual lanthanide ions calculated from the Dubinin-Radushkevich equation are from $E=11.2$ to $E=11.5 \mathrm{~kJ} / \mathrm{mol}$, which is characteristic of the chemical adsorption mechanism. In the case of lanthanide ions, ion exchange adsorption between $\mathrm{Mg}^{2+}$ ions and $\mathrm{Ln}^{3+}$ ions could possibly be a major process.

The increase of $\mathrm{U}(\mathrm{VI})$ adsorption on natural sepiolite was very quick at initial contact (Figure $5 \mathrm{c}$ ). The maximum amount of adsorbed uranium was obtained after just $60 \mathrm{~min}$. Then, $360 \mathrm{~min}$ after the start, desorption of uranium previously adsorbed by sepiolite was observed. An increase in uranium adsorption was found later. However, the amount of adsorbed ions was much smaller than in the first period of fast adsorption. A similar decrease in the case of adsorption of uranium on diatomite from $40 \mathrm{~min}$ to $90 \mathrm{~min}$ after the start was observed by Sprynskyy et al. [34]. The uranium desorption is explained by the authors based on the fact that exchangeable cations and diatomite surface hydrogen ions compete with the solution's uranium ions. The U(VI) adsorption on ODTMA-sepiolite was also fast for the first hour of contact time, then increased slowly with time. In this case, there was no decrease in adsorption with time progression. The fast $\mathrm{U}(\mathrm{VI})$ adsorption on ODTMA-sepiolite may indicate its dominance due to chemical adsorption through surface complexation but not physical adsorption. The analysis of the data of $\mathrm{U}(\mathrm{VI})$ adsorption on sepiolite was made by three kinetic models: the pseudo-first-order:

$$
\log \left(q_{e}-q_{t}\right)=\log q_{e}-\left(\frac{k_{1}}{2.303}\right) \times t
$$

the pseudo-second-order:

$$
\frac{t}{q_{t}}=\frac{1}{k_{2} q_{e}^{2}}+\left(\frac{1}{q_{e}}\right) \times t
$$

The Weber-Morris intraparticle diffusion model expressed as:

$$
q_{t}=k_{3} \times t^{0.5}
$$


where $q_{e}$ and $q_{t}$ indicate the amounts of uranium ions adsorbed at equilibrium in $\mathrm{mg} / \mathrm{g}$, and at time $t$ in min, respectively, and $k_{1}, k_{2}$ and $k_{3}$ show the rate constants. The calculated parameters and correlation coefficients $\left(R^{2}\right)$ values are presented in Table 5. For high correlation coefficient values, it can be deduced that the sorption system is based on the pseudo-second order kinetic model. The adsorption mechanism proceeds mainly by chemisorption (especially ion exchange), as adsorption follows the pseudo-second order model [35].
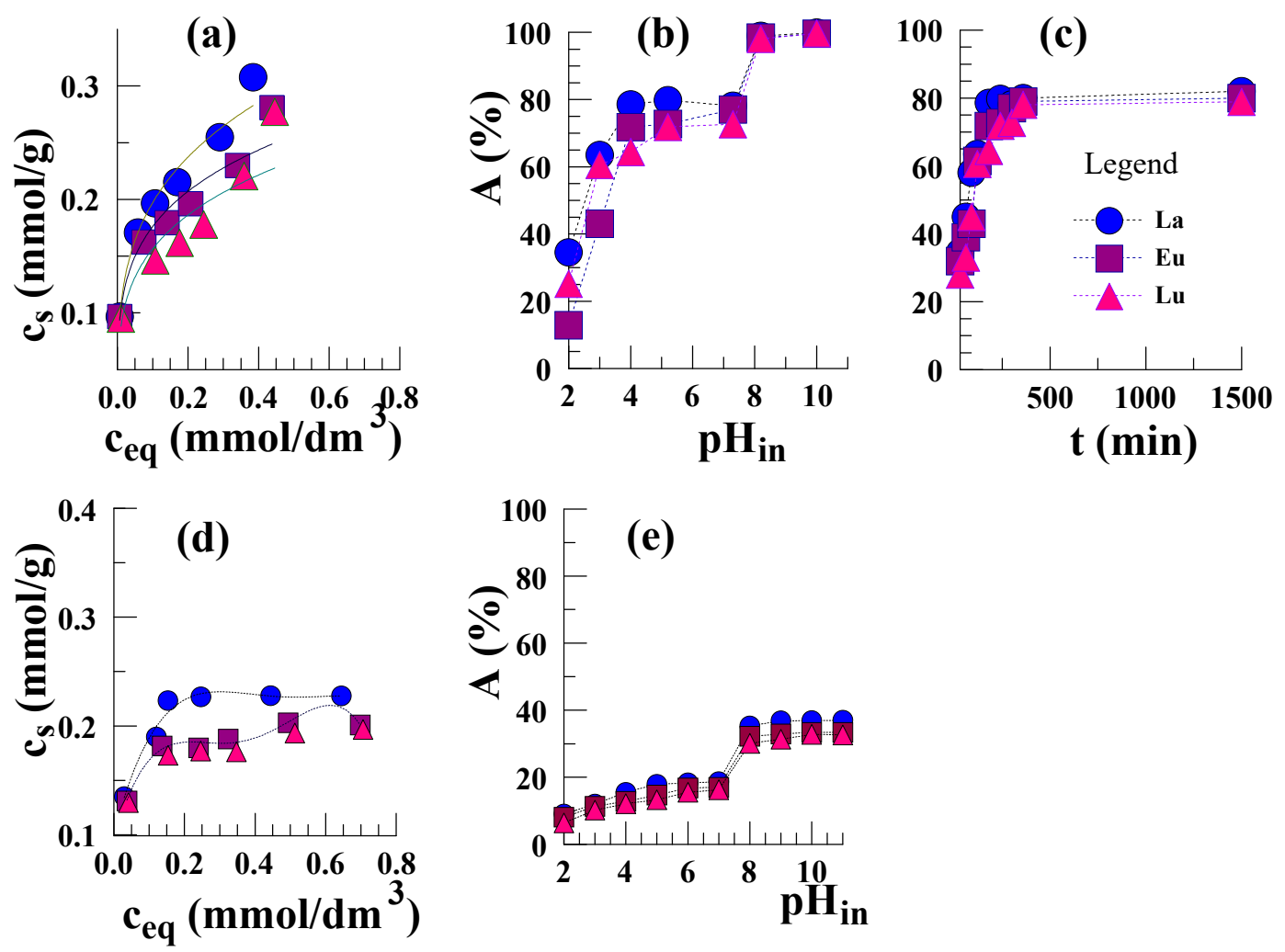

Figure 6. The effect of initial concentration (a), $\mathrm{pH}(\mathbf{b})$, and time (c) on lanthanide ions' adsorption on natural sepiolite and ODTMA-sepiolite $(\mathbf{d}, \mathbf{e})$ at $23^{\circ} \mathrm{C}$. (Coloured figures online.)

Lanthanide ions' adsorption on natural sepiolite remains constant at around $80 \%$ after $3 \mathrm{~h}$. The parameters of kinetic models used in calculations are presented in Table 5.

The effect of $\mathrm{pH}$ on ions adsorption on sepiolite is of importance. As follows from Figure $5 \mathrm{~b}$, uranyl ions' adsorption on both sorbents grows when the $\mathrm{pH}$ values increase at $\mathrm{pH}<6$, reaching the maximal value at $\mathrm{pH} 6-8$; it then drops when the $\mathrm{pH}$ value increases. Uranium ions adsorption on clay follows the outer sphere or ion exchange complexation with low values of $\mathrm{pH}$ as well as that of inner sphere when the $\mathrm{pH}$ values are high. Furthermore, the increase of $\mathrm{pH}$ favors the formation of oligomeric uranium hydroxy complexes, especially $\left(\mathrm{UO}_{2}\right)(\mathrm{OH})^{+},\left(\mathrm{UO}_{2}\right)_{3}(\mathrm{OH})_{5}{ }^{+}$and $\left(\mathrm{UO}_{2}\right)_{4}(\mathrm{OH})_{7}{ }^{+}$ species [36], which occupy more active adsorption sites on the mineral surface than simple $\mathrm{UO}_{2}{ }^{+}$cation. The decrease of adsorption can be justified by various anionic uranium(VI) complexes present at different values of $\mathrm{pH}$. According to Han et al. [37], at $\mathrm{pH}>6$, the amount of dissolved anion complexes with $\mathrm{U}(\mathrm{VI})$ grows, resulting in decreasing $\mathrm{U}(\mathrm{VI})$ adsorption on unmodified sepiolite. In the case of ODTMA-sep, the U(VI) adsorption decrease at higher values of $\mathrm{pH}$ is negligible due to interactions of anionic complexes with a positively charged mineral surface. The adsorption of lanthanide ions increases with the increasing $\mathrm{pH}$ and is established at a constant level of about $80 \%$ for the $\mathrm{pH}$ range of 4-8 (Figure $6 \mathrm{~b}, \mathrm{e}$ ). In this area of $\mathrm{pH}$, the exchange between the $\mathrm{H}^{+}$ions coming from the silanol group contained in the sepiolite structure and lanthanide ones occurring in the form of $\mathrm{Ln}^{3+}$ ions or hydroxycomplexes $\mathrm{Ln}(\mathrm{OH})^{2+}$ and $\mathrm{Ln}(\mathrm{OH})_{2}{ }^{+}$is most likely a chemisorption reaction. Further increase in $\mathrm{pH}$ leads to an increase in adsorption to $98 \%$, which is probably due to the precipitation of lanthanide 
hydroxides $\mathrm{Ln}(\mathrm{OH})_{3}$ at $\mathrm{pH}$ above 8 . This fact leads to a decrease in their concentration in equilibrium solutions and, as a result, an increase in the percentage of lanthanide adsorption on sepiolite is observed. Such precipitated hydroxides or carbonates settle down on the sepiolite surface or are partially complexed by it.

It is evident from Figure 6d,e that the adsorption of lanthanide ions on ODTMA-sepiolite is much lower. This is due to the presence of ODTMA ${ }^{+}$ions on the sepiolite surface, which makes it positively charged and thus prevents interactions with $\mathrm{Ln}^{3+}$ cations. In addition, the large ODTMA ${ }^{+}$ions clog up the sepiolite pores and make access to the lanthanide cations difficult.

\subsection{Proposed Mechanism of Adsorption}

Based on the FTIR, XPS analysis, and batch studies, the probable adsorption mechanism of lanthanides and uranium(VI) ions on sepiolite can be suggested. One of the possible adsorption mechanisms is ion exchange between $\mathrm{H}^{+}$from silanols $\left(\equiv \mathrm{Si}-\mathrm{OH}\right.$ ) or/and $\mathrm{Mg}^{2+}$ cations derived from the octahedral sheet in the sepiolite structure and the lanthanides or uranium cations. The reactions depend on the $\mathrm{pH}$ of the solutions. This includes $\mathrm{UO}_{2}{ }^{2+}$ ions $(\mathrm{pH}<4)$ or the hydroxy complexes, especially $\left(\mathrm{UO}_{2}\right)_{3}(\mathrm{OH})_{5}{ }^{+},\left(\mathrm{UO}_{2}\right)(\mathrm{OH})^{+},\left(\mathrm{UO}_{2}\right)(\mathrm{OH})_{3}{ }^{-}$and $\left(\mathrm{UO}_{2}\right)(\mathrm{OH})_{4}{ }^{2-}(\mathrm{pH}>4)$ in the case of uranium ions or $\mathrm{Ln}^{3+}$ and $\mathrm{Ln}\left(\mathrm{NO}_{3}\right)^{+}(\mathrm{pH}<4)$ or $\mathrm{Ln}(\mathrm{OH})_{2}{ }^{+}$and $\mathrm{Ln}(\mathrm{OH})^{2+}(\mathrm{pH}>4)$. In addition, there are also interactions between the oxygen from the silanol groups and the uranium ions. The anionic uranium complexes present at $\mathrm{pH}>5$ also play also a significant role in adsorption, as they interact with the alkyl chains of the surfactant cations attached to the sepiolite surface. In the case of lanthanides, the precipitation of lanthanide hydroxides $\mathrm{Ln}(\mathrm{OH})_{3}$ also probably occurs at $\mathrm{pH}>8$. Each of the mentioned mechanisms is feasible and its action is strongly dependent on the $\mathrm{pH}$ of the reaction environment. The following reactions are possible:

$$
\begin{aligned}
& \equiv \mathrm{Si}-\mathrm{OH}+\left(\mathrm{UO}_{2}\right)_{3}(\mathrm{OH})_{5}{ }^{+} \leftrightarrow \equiv \mathrm{Si}-\mathrm{O}\left(\mathrm{UO}_{2}\right)_{3}(\mathrm{OH})_{5}+\mathrm{H}^{+} \\
& \equiv 2 \mathrm{~S}-(\mathrm{ODTMA})_{2}+\left(\mathrm{UO}_{2}\right)_{2}(\mathrm{OH})_{4}{ }^{2-} \leftrightarrow\left[\equiv \mathrm{S}-(\mathrm{ODTMA})_{2}\right]_{2}\left(\mathrm{UO}_{2}\right)_{2}(\mathrm{OH})_{4} \\
& \equiv 2 \mathrm{Si}-\mathrm{OH}+\mathrm{UO}_{2}{ }^{2+} \leftrightarrow\left[\equiv \mathrm{Si}-\mathrm{O}_{2} \mathrm{UO}_{2}+2 \mathrm{H}^{+}\right. \\
& \equiv 3 \mathrm{Si}-\mathrm{OH}+\mathrm{Ln}^{3+} \leftrightarrow[\equiv \mathrm{Si}-\mathrm{O}]_{3}-\mathrm{Ln}+3 \mathrm{H}^{+} \\
& \equiv \mathrm{Si}-\mathrm{O}-(\mathrm{Mg})_{3}+2 \mathrm{Ln}^{3+} \leftrightarrow \equiv \mathrm{Si}-\mathrm{O}-(\mathrm{Ln})_{2}+3 \mathrm{Mg}^{2+}
\end{aligned}
$$

\subsection{Comparison of ODTMA-Sepiolite with Other Adsorbents}

The adsorbent ODTMA-sepiolite proved be very effective for uranium ions' removal from aqueous solutions and sepiolite for lanthanides. The maximum adsorption capacity $\left(q_{\max }\right)$ is $285.6 \mathrm{mg} / \mathrm{g}$ for $\mathrm{U}(\mathrm{VI})$ and $91.6,91.4,104.9 \mathrm{mg} / \mathrm{g}$ for $\mathrm{La}(\mathrm{III}), \mathrm{Eu}(\mathrm{III}), \mathrm{Lu}(\mathrm{III})$, respectively. It is compared to those of the reported best uranium adsorbents (Table 6) and much higher than those of commercial $\mathrm{UO}_{2}{ }^{2+}$ scavengers. The adsorption capacity $\left(q_{\max }\right)$ for achieving an equilibrium condition is an important parameter determining the sorption potential of an adsorbent towards a given analyte. It can be seen that the adsorption on ODTMA-sepiolite is much more effective than that of all compared adsorbents and very similar to the HDTMA-sepiolite case $(212 \mathrm{mg} / \mathrm{g})$, i.e., to sepiolite modified by hexadecyltrimethylammonium bromide [33]. The longer alkyl chain in the ODTMA cation structure and consequently, its higher hydrophobicity compared with HDTMA is the main factor affecting the partition of the uranyl ions between the aqueous and sepiolite phases. In turn, the lower capacity of the studied unnmodified sepiolite can be interpreted by the lack of surfactant on the surface and thus the absence of binding groups of uranium complexes. 
Therefore, these advantages combined with very high loading capacity, low cost, environmentally friendly nature, and facile syntheses make ODTMA-sepiolite promising for the removal and recovery of uranyl ions from aqueous solutions and sludge.

Table 6. Comparison of the adsorption capacity $\left(q_{\max }\right) \mathrm{U}(\mathrm{VI})$ and $\mathrm{Ln}(\mathrm{III})$ ions of the studied adsorbents with other adsorbents reported in the literature.

\begin{tabular}{|c|c|c|c|c|c|}
\hline \multirow{2}{*}{ Sorbent } & \multicolumn{4}{|c|}{ Sorption Capacity, $q_{\max }, \mathrm{mg} / \mathrm{g}$} & \multirow{2}{*}{ References } \\
\hline & La(III) & Eu(III) & Lu(III) & $\mathrm{U}(\mathrm{VI})$ & \\
\hline $\mathrm{TiO}_{2}$ & & & & 44 & [38] \\
\hline HDTMA $^{+}$-pillared bentonite Na-bentonite & & & & 106.465 & [39] \\
\hline Organo-halloysite & & & & 157 & [40] \\
\hline HDTMA-sepiolite & & & & 212 & {$[33]$} \\
\hline Sodium bentonite activated clay & & & & 11.8 & {$[41]$} \\
\hline Carbon modified with tetraoctyldiglycolamide (TODGA) & & 18 & & & [42] \\
\hline Montmorillonite-carbon composite & & & & 20.8 & [6] \\
\hline Mesocellular siliceous foam polymer & 136 & 138 & 147 & & [43] \\
\hline Activated Carbon from Banana Peels (Musa Paradisiaca L.) & 67 & - & - & - & [44] \\
\hline Biohydroxyapatite & 17 & & & & [45] \\
\hline Biomass Mycobacterium smegmatis & 55 & 49 & & 114 & [46] \\
\hline Amidoxime-Hydroxamic Acid Polymer & 69 & & & & [47] \\
\hline Activated carbon & & & & 158 & [48] \\
\hline Zeolite- $\mathrm{MnO}_{2}$ & & & & 180 & [37] \\
\hline Kaolin & & & & 4.5 & [32] \\
\hline Calcined $\mathrm{Mg}$-Al hydrotalcite & & & & 42.4 & [49] \\
\hline Sepiolite & 91.6 & 91.4 & 104.9 & 142.8 & This work \\
\hline ODTMA-sepiolite & & & & 285.6 & This work \\
\hline
\end{tabular}

\section{Conclusions}

1. ODTMA-sepiolite is a more effective adsorbent for $\mathrm{U}(\mathrm{VI})$ ions and sepiolite for lanthanide ions. The capacity towards U(VI) $285.6 \mathrm{mg} / \mathrm{g}(1.2 \mathrm{mmol} / \mathrm{g})$ makes this adsorbent one of the most commonly used in uranium recovery from aqueous solutions. As for lanthanides, the ion exchange capacity of sepiolite was: $\mathrm{La}(\mathrm{III})-91.6 \mathrm{mg} / \mathrm{g}(0.6 \mathrm{mmol} / \mathrm{g}), \mathrm{Eu}(\mathrm{III})-91.4 \mathrm{mg} / \mathrm{g}(0.6 \mathrm{mmol} / \mathrm{g})$, and Lu(III)-104.9 mg/g $(0.66 \mathrm{mmol} / \mathrm{g})$.

2. FTIR spectroscopy of the adsorption products show that the surfactant cations ODTMA $^{+}$form a bilayer on the mineral surface; thus, there are electrostatic interactions of surfactant cations with the silicate framework of sepiolite, as well as Van der Waals ones of excessive ODTMA ${ }^{+}$cations with those already bound.

3. The TRLFS analysis of uranium adsorbed on the sepiolite surface points to at least two surface species of two short- and one long- lived ones. Their average fluorescence lifetime is: for short $(\tau 1)$ and long-lived ( $\tau 2)$ forms of U-sepiolite: $\tau 1=2420 \pm 430 \mathrm{~ns}$ and $\tau 2=37950 \pm 5710 \mathrm{~ns}$, for U-ODTMA-sepiolite: $\tau 1=3523 \pm 160 \mathrm{~ns}$, and $\tau 2=45400 \pm 1830 \mathrm{~ns}$. More water molecules in the coordination environment indicate a shorter lifetime of fluorescence due to their quenching by water molecules [23,25]. Thus, $\mathrm{U}(\mathrm{VI})$ forms two surface species on sepiolite that differ in the number of water molecules in the coordination environment.

Funding: The financial support from the National Centre of Research and Development (Poland) within project No. POIR.04.01.01-00-0040/17-00 is acknowledged.

Conflicts of Interest: The author declares no conflict of interest.

\section{References}

1. Qafoku, N.P.; Icenhower, J.P. Interactions of aqueous U(VI) with soil minerals in slightly alkaline natural systems. Rev. Environ. Sci. Biotechnol. 2008, 7, 355-361. [CrossRef]

2. Xie, S.; Zhang, C.; Zhou, X.; Yang, J.; Zhang, X.; Wang, J. Removal of uranium (VI) from aqueous solution by adsorption of hematite. J. Environ. Radioact. 2009, 100, 162-168. 
3. Zakutevskii, O.I.; Psareva, T.S.; Strelko, V.V.; Kartel, N.T. Sorption of U(VI) from Aqueous Solutions with Carbon Sorbents. Radiochemistry 2007, 49, 67-73. [CrossRef]

4. Yusan, S.; Erenturk, S.A. Adsorption equilibrium and kinetics of U(VI) on beta type of akaganeite. Desalination 2010, 263, 233-239. [CrossRef]

5. Zhang, X.; Jiao, C.; Wang, J.; Liu, Q.; Li, R.; Yang, P.; Zhang, M. Removal of uranium(VI) from aqueous solutions by magnetic Schiff base: Kinetic and thermodynamic investigation. Chem. Eng. J. 2012, 198, 412-420. [CrossRef]

6. Zhang, R.; Chen, C.; Li, J.; Wang, X. Preparation of montmorillonite@carbon composite and its application for U(VI) removal from aqueous solution. Appl. Surf. Sci. 2015, 349, 129-133. [CrossRef]

7. Arnold, T.; Zorn, T.; Zanker, H.; Bernhard, G.; Nitsche, H. Sorption behavior of U(VI) on phyllite: Experiments and modeling. J. Contam. Hydrol. 2001, 47, 219-225. [CrossRef]

8. Filipi, R.; Nesmerak, K.; Rucki, M.; Roth, Z.; Hanzlikova, I.; Tichy, M. Acute toxicity of rare earth elements and their compounds. Chem. Listy 2007, 101, 793-798.

9. Gladysz-Plaska, A.; Majdan, M.; Ferenc, W.; Sarzynski, J. Comparison of covalency in the lanthanide chloride and nitrate complexes based on the adsorption data on zeolite Y. J. Mol. Struct. 2011, 3, 469-474. [CrossRef]

10. Majdan, M.; Pikus, S.; Gladysz-Plaska, A.; Fuks, L.; Zieba, E. Adsorption of light lanthanides on the zeolite A Surface. Colloids Surf. A 2002, 209, 27-35. [CrossRef]

11. Donat, R. The removal of uranium (VI) from aqueous solutions onto natural sepiolite. J. Chem. Thermodyn. 2009, 41, 829-834. [CrossRef]

12. Özdemir, O.; Cınar, M.; Sabah, E.; Arslan, F.; Celik, M.S. Adsorption of anionic surfactants onto sepiolite. J. Hazard. Mater. 2007, 147, 625-631. [CrossRef] [PubMed]

13. Xi, Y.; Ding, Z.; He, H.; Frost, R.L. Structure of organo-clays-An X-ray diffraction and thermogravimetric analysis study. J. Colloid Interface Sci. 2001, 277, 116-120. [CrossRef] [PubMed]

14. Xi, Y.; Frost, R.L.; He, H.; Kloprogge, T.; Bostrom, T. Modification of Wyoming montmorillonite surfaces using a cationic surfactant. Langmuir 2005, 21, 8675-8680. [CrossRef]

15. He, H.; Ding, Z.; Zhu, J.; Yuan, P.; Xi, Y.; Yang, D.Y.; Frost, R.L. Thermal characterization of surfactant-modified montmorillonites. Clays Clay Miner. 2005, 53, 287-293. [CrossRef]

16. He, H.; Frost, R.L.; Bostrom, T.; Yuan, P.; Duong, L.; Yang, D.; Xi, Y.; Kloprogge, T.J. Changes in the morphology of organoclays with HDTMA ${ }^{+}$surfactant loading. Appl. Clay Sci. 2006, 31, 262-271. [CrossRef]

17. Cody, C.A.; Kemnetz, S. Process for the Removal of Heavy Metals from Aqueous Systems Using Organoclays. European Patent EPO765842, 1999.

18. Dolatyari, L.; Yaftian, M.R.; Rostamnia, S. Removal of uranium(VI) ions from aqueous solutions using Schiff base functionalized SBA-15 mesoporous silica materials. J. Environ. Manag. 2016, 169, 8-15. [CrossRef]

19. Gładysz-Płaska, A.; Grabias, E.; Majdan, M. Simultaneous adsorption of uranium(VI) and phosphate on red clay. Prog. Nucl. Energy 2018, 104, 150-159. [CrossRef]

20. Majdan, M.; Pikus, S.; Gajowiak, A.; Sternik, D.; Zieba, E. Uranium sorption on bentonite modified by octadecyltrimethylammonium bromide. J. Hazard. Mater. 2010, 184, 662-667. [CrossRef]

21. Choi, S.S.; Lee, J.H.; Jin, J.M.; Lee, S.H. Adsorption characteristics of volatile organic compounds onto lyocell-based activated carbon fibers. Carbon Lett. 2019, 39, 1-10.

22. Liu, X.; Wang, L.; Zheng, Z.; Kang, M.; Li, C.; Liu, C. Molecular dynamics simulation of the diffusion of uranium species in clay pores. J. Hazard. Mater. 2013, 245, 21-28. [CrossRef] [PubMed]

23. Zhang, G.; Liu, J.; Zheng, S.; Hashisho, Z. Adsorption of volatile organic compounds onto natural porous materials. J. Hazard. Mater. 2019, 364, 317-324. [CrossRef] [PubMed]

24. Buekens, A.; Zyaykina, N.N. Adsorbents and Adsorption Processes for Pollution Control, Pollution Control Technologies-Vol. II. In Adsorbents and Adsorption Processes for Pollution Control; Encyclopedia of Life Support Systems (EOLSS): Brussel, Belgium, 2013; pp. 1-10.

25. Huang, M.-C.; Chou, C.-H.; Teng, H. Pore-Size Effects on Activated-Carbon Capacities for Volatile Organic Compound Adsorption. Mater. Interfaces Electrochem. Phenom. 2002, 48, 1804-1810. [CrossRef]

26. Artner, C.; Kronister, S.; Czakler, M.; Schubert, U. Ion-Size-Dependent Formation of Mixed Titanium/Lanthanide Oxo Clusters. Eur. J. Inorg. Chem. 2014, 32, 5596-5602. [CrossRef]

27. Liang, X.; Xu, Y.; Sun, G.; Wang, L.; Sun, Y.; Qin, X. Preparation and characterization of mercapto functionalized sepiolite and their application for sorption of lead and cadmium. Chem. Eng. J. 2011, 174, 436-444. [CrossRef] 
28. Liu, J.; Zhao, C.; Tu, H.; Yang, J.; Li, F.; Li, D.; Liao, X.; Yang, Y.; Tang, J.; Liu, N. U(VI) adsorption onto cetyltrimethylammonium bromide modified bentonite in the presence of $\mathrm{U}(\mathrm{VI})-\mathrm{CO}_{3}$ complexes. Appl. Clay Sci. 2017, 135, 64-74. [CrossRef]

29. Křepelovă, A. Influence of Humic Acid on the Sorption of Uranium(VI) and Americium(III), Disseration; University of Technology: Dresden, Germany, 2007.

30. Baumann, N.; Brendler, V.; Arnold, T.; Geipel, G.; Bernhard, G. Uranyl sorption onto gibbsite studied by time-resolved laser-induced fluorescence spectroscopy (TRLFS). J. Colloid Interface Sci. 2005, 290, 318-322. [CrossRef]

31. Trepte, P. Sorption von Radionukliden an Tongestein: Spektroskopische Referenzdaten. Master's Thesis, University of Applied Science, Dresden, Germany, 2006.

32. Wang, G.; Wang, X.; Chai, X.; Liu, J.; Deng, N. Adsorption of uranium (VI) from aqueous solution on calcined and acid-activated kaolin. Appl. Clay Sci. 2010, 47, 448-455. [CrossRef]

33. Gajowiak, A.; Gładysz-Płaska, A.; Sternik, D.; Pikus, S.; Sabah, E.; Majdan, M. Sorption of uranyl ions on organosepiolite. Chem. Eng. J. 2013, 219, 459-468. [CrossRef]

34. Sprynskyy, M.; Kovaluk, I.; Buszewski, B. The separation of uranium ions by natural and modified diatomite from aqueous solution. J. Hazard. Mater. 2010, 181, 700-710. [CrossRef] [PubMed]

35. Ho, Y.S.; McKay, G. Pseudo-second order model for sorption processes. Process. Biochem. 2009, 34, 451-459. [CrossRef]

36. Liu, Y.; Li, Q.; Cao, X.; Wang, Y.; Jiang, X.; Li, M.; Hua, M.; Zhang, Z. Removal of uranium(VI) from aqueous solutions by CMK-3 and its polymer composite. Appl. Surf. Sci. 2013, 285, 258-264. [CrossRef]

37. Han, R.P.; Zou, W.H.; Wang, Y.; Zhu, L. Removal of uranium (VI) from aqueous solutions by manganese oxide coated zeolite: Discussion of adsorption isotherms and pH effect. J. Environ. Radioact. 2007, 93, 127-133. [CrossRef] [PubMed]

38. Wang, G.; Zhen, J.; Zhou, L. Adsorption and photocatalytic reduction of $\mathrm{U}(\mathrm{VI})$ in aqueous $\mathrm{TiO}_{2}$ suspensions enhanced with sodium formate. J. Radioanal. Nucl. Chem. 2015, 304, 579-585. [CrossRef]

39. Wang, Y.Q.; Zhang, Z.B.; Liu, Y.H. Adsorption of uranium from aqueous solution using HDTMA ${ }^{+}$-pillared bentonite: Isotherm, kinetic and thermodynamic aspects. J. Radioanal. Nucl. Chem. 2012, 293, 231-239. [CrossRef]

40. Gładysz-Płaska, A.; Majdan, M.; Tarasiuk, B.; Sternik, D.; Grabias, E. The use of halloysite functionalized with isothiouronium salts as an organic/inorganic hybrid adsorbent for uranium(VI) ions removal. J. Hazard. Mater. 2018, 354, 133-144. [CrossRef]

41. Youssef, W.M. Uranium Adsorption from Aqueous Solution Using Sodium Bentonite Activated Clay. J. Chem. Eng. Process Technol. 2017, 8, 157-170.

42. Turanov, A.; Karandashev, V.; Sukhinina, N.; Masalov, V.; Zhokhov, A.; Emelchenko, G. A novel sorbent for lanthanide adsorption based on tetraoctyldiglycolamide, modified carbon inverse opals. RSC Adv. 2015, 5, 529-535. [CrossRef]

43. Li, W.; Lin, P.; Dai, S.; Sun, X.; Shen, Y. Preparation of a mesocellular siliceous foam supported lanthanide-sensitive polymer for the selective adsorption of lanthanides. Dalton Trans. 2018, 47, 4840-4849. [CrossRef]

44. Kusrini, E.; Kinastiti, D.D.; Wilson, L.D.; Usman, A.; Rahman, A. Adsorption of lanthanide ions from an aqueous solution in multicomponent systems using activated carbon from banana peels (Musa paradisiaca L.). Int. J. Technol. 2018, 6, 1132-1139. [CrossRef]

45. Szczepaniak, W.; Zabłocka-Malicka, M.; Pasiecznik, I.; Pohl, P.; Rutkowski, P. Adsorption of La ${ }^{3+}$ and Dy ${ }^{3+}$ ions on biohydroxyapatite obtained from pork bones gasified with steam. Environ. Prot. Eng. 2018, 44, $29-40$.

46. Andres, Y.; MacCordick, H.J.; Hubert, J.-C. Adsorption of several actinide (Th, U) and lanthanide (La, Eu, Yb) ions by Mycobacterium smegmatis. Appl. Microbiol. Biotechnol. 1993, 39, 413-417. [CrossRef]

47. Alakhras, F. Kinetic Studies on the Removal of Some Lanthanide Ions from Aqueous Solutions Using Amidoxime-Hydroxamic Acid Polymer. J. Anal. Methods Chem. 2018, 2018, 4058503. [CrossRef]

48. Belgacem, A.; Rebiai, R.; Hadoun, H.; Khemaissia, S.; Belmedani, M. The removal of uranium (VI) from aqueous solutions onto activated carbon developed from grinded used tire. Environ. Sci. Pollut. Res. 2014, 21, 684-689. [CrossRef] 
49. Durán-Blanco, J.M.; López-Muñoz, B.E.; Olguín, M.T. Influence of pH on U(VI) Adsorption using a Thermally-Treated Mg-Al Hydrotalcite and a Natural Zeolite in a Batch System. Separ. Sci. Technol. 2013, 48, 797-809. [CrossRef] 